UNITED STATES

DEPARTMENT OF THE INTERIOR

GEOLOGICAL SURVEY

\title{
PRELIMINARY REPORT ON THE LIGNITE RESOURCES \\ OF THE NIOBE AREA, \\ BURKE AND WARD COUNTIES, NORTH DAKOTA
}

By

Hal E. Owen

Open-File Report 77-379

1977

OPEN-FILE REPORT

This report has not been edited

for conformity with Geological

Survey editorial standards or

stratigraphic nomenclature. 


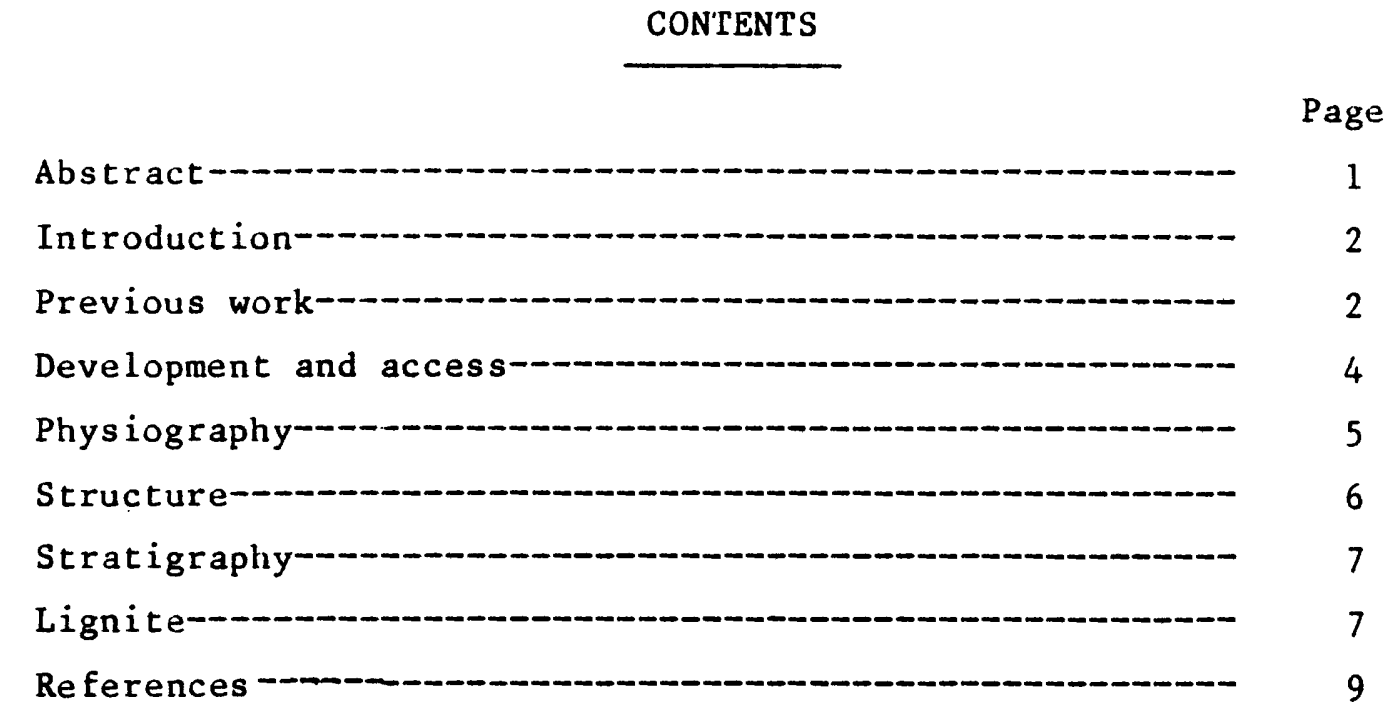

\section{ILLUSTRATIONS \\ (plates in pocket)}

Figure 1. Index map of Niobe area- 3

Plate 1. Dril1-hole data map

2. Geomorphic features of the Niobe area

3. Contour map of bedrock surface

4. Structure contour map - Niobe bed

5. Structure contour map - Bonus bed

6. Dril1-hole correlation chart

7. Isopach map of Niobe bed

8. Overburden isopach map - Niobe bed

9. Interburden isopach map

10. Isopach map of Bonus bed

11. Overburden isopach map - Bonus bed

\section{TABLE \\ (in pocket)}

Table 1. Compilation of drill-hole data on Niobe and Bonus lignite beds for Niobe area. 
PRELIMINARY REPORT ON THE LIGNITE RESOURCES OF THE

NIOBE AREA, BURKE AND WARD COUNTIES, NORTH DAKOTA

By Hal E. Owen

\begin{abstract}
Two lignite beds, the Niobe and the Bonus, occur at strippable depths within the Niobe area. The Niobe bed averages 5 feet ( 1.5 meters) in thickness and the Bonus bed averages 8 feet (2.4 meters) in thickness. These beds lie in the lower part of the Sentinel Butte Member of the Fort Union Formation (Paleocene).

The demonstrated resources of both beds combined is 122 million tons (110 million tonnes), all of which are under less than 120 feet (37 meters) of overburden. The overburden consists of glacial till and shale.

The lateral continuity of the coal has been locally interrupted by faulting, glacial outwash channels, and erosion. Folding and/or faulting occurs parallel to the Missouri Coteau escarpment and faulting occurs roughly perpendicular to the escarpment.
\end{abstract}




\section{Introduction}

The Niobe area lies in Burke and Ward Counties in northwestern North Dakota (fig. 1). U.S. Geological Survey $7 \frac{1}{2}$-minute topographic quadrangle maps of Vanville $\mathrm{NE}$, Vanville SE, Mosquito Butte, and Niobe, North Dakota, cover this area, which is underlain by the coal-bearing Fort Union Formation (Paleocene). The boundary of the area is based on the Niobe and Bonus lignite beds, which average $5 \mathrm{ft}(1.5 \mathrm{~m})$ and $8 \mathrm{ft}$ (2.4) in thickness, respectively. The Bonus bed is stratigraphically $18-56 \mathrm{ft}(5.5-17.1 \mathrm{~m})$ above the Niobe bed.

\section{Previous Work}

Wilder and Wood (1902, p. 106-119) discussed the lignite bed in Ward County. Leonard, Babcock, and Dove (1925) described the lignite deposits and the locations of operating mines in Burke and Ward Counties. Lemke (1960) mapped the surface geology in his study of the Souris River area, and Freers (1973) elaborated on the glacial deposits of Burke County. In 1966, Bauko1-Noonan, Inc. and Great Northern Railroad (now Burlington Northern, Inc.) jointly drilled 76 coal exploration holes in the Niobe area. Pollard, Smith, and Knox (1972) published most of this information and calculated strippable coal resources. The drill-hole information published by Pettyjohn (1968) and Armstrong (1969) includes wells drilled by: North Dakota State Water Commission, U.S. Air Force, and B. Mortensen. The information from B. Mortensen was data from private drilling which he donated to the North Dakota State Water Commission. All of this drill-hole information has been compiled in table 1 . 

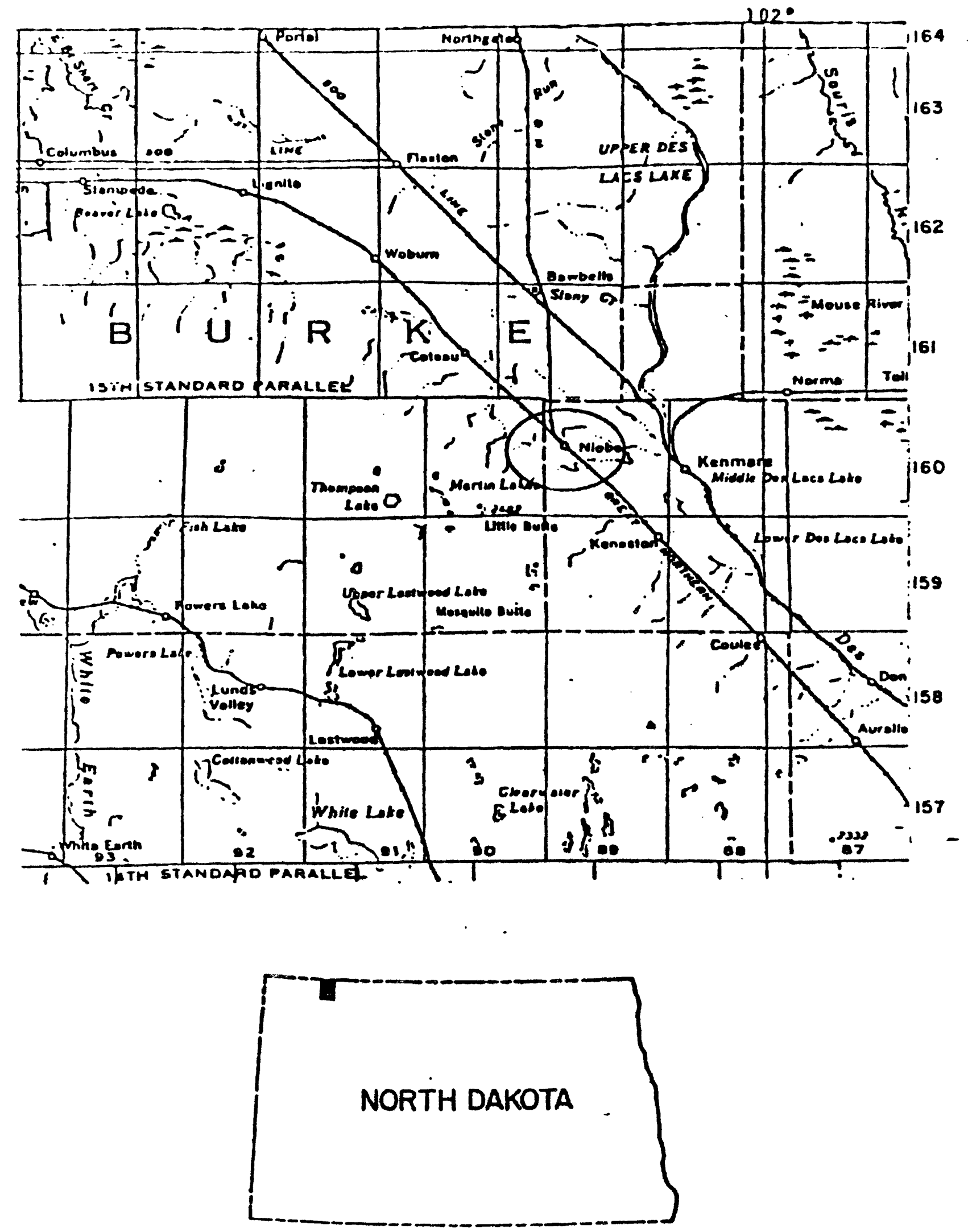

Figrre 1.--Index Map of the Niobe area, Burke and Ward Counties, North Dakota 


\section{Development and Access}

Forty-four mines have been in operation at different times in Burke County, with most of the activity concentrated around the town of Columbus, $28 \mathrm{mi}(45.1 \mathrm{~km})$ northwest of Niobe (fig. 1). Prior to 1950 , total lignite production in the county was $8,730,000$ tons $(7,919,681$ t) (Brant, 1953, p. 19). Coal mined from the Noonan bed, near Noonan, North Dakota, from July 1, 1970 to June 30, 1971, was 523,229 tons $(474,663 \mathrm{t})$ valued at $\$ 970,000$ (Freers, 1973, p. 21).

In Ward County, coal has been mined in the Kenmare vicinity along Des Lacs Lake (Wilder and Wood, 1902, p. 109 (fig. 1). More than 70 mines have operated in Ward County. Total county production prior to 1951 was $13,034,202$ tons $(11,824,367$ t) (Brant, 1953, p. 21).

Within the area, development has been limited to three small mines, now abandoned (Lemke, 1960, pl. 1, west half; and pl. 1 of this report). Production figures and coal analyses are not available for these mines.

The Niobe area is accessible from U.S. HIghway 52 on the east and State Route 8 on the west. A branch line of the Burlington Northern railroad runs parallel to, and half a mile northeast of, the Niobe bed subcrop.

A water source for future development may be the Upper Des Lacs Lake about $6 \mathrm{mi}(10 \mathrm{~km})$ to the northeast (fig. 1). Buried glacial channels between Niobe and Des Lacs Lakes are potential sources of additional water. 


\section{Physiography}

The Niobe area is composed of three morphologic units: (1) the Missouri Coteau slope, (2) the Missouri Coteau escarpment, and (3) the Missouri Coteau. The Coteau slope (northeastern portion of pl. 2), a gently undulating glaciated slope of low relief and integrated drainage, marks the southwestern limit of glacial Lake Souris (Andrews, 1939, p. 61). The bedrock surface (p1. 3) and the ground surface both slope to the northeast.

The Missouri Coteau escarpment is an area where the land surface rises abruptly. According to Lemke (1960, p. 108), it may be caused by faulting. At one point, near Niobe, the escarpment slopes $7^{\circ}$, with the surface elevation increasing from $2,200 \mathrm{ft}(671 \mathrm{~m})$ to $2,350 \mathrm{ft}$ $(716 \mathrm{~m})$ within a distance of $1,200 \mathrm{ft}(366 \mathrm{~m})$. Because of glacial cover and lack of drill-hole data, it is unknown if bedrock is faulted in this area.

The Missouri Coteau is a topographic high and marks the farthest advance of the Wisconsinan (Pleistocene) ice fronts. The Coteau is mantled by as much as $200 \mathrm{ft}(61 \mathrm{~m})$ of $t 111$ and is characterized by hummocky topography with deranged drainage. The Coteau is $15-20 \mathrm{mi}$ $(24-32 \mathrm{~km}$ ) wide and trends southeastward through both Burke and Ward Counties. In this region the Coteau is the divide between the Gulf of Mexico and Hudson Bay drainage systems. 


\section{Structure}

The Niobe area lies on the northeastern flank of the Williston basin; however, the dip in this area is directly opposite the regional dip. This reversal in dip is caused by a structural high that may be the Missouri Coteau (Townsend, 1950, p. 1563; Lemke, 1960, p. 107). Both the Niobe and Bonus coal beds strike northwestward roughly parallel to the escarpment and, on the average, dip $1 / 4^{\circ}-1 / 2^{\circ}$ to the northeast (p1s. 4 and 5). Near the escarpment the coal beds reach their maximum northeast dip $(120 \mathrm{ft} / \mathrm{mi} ; 22.7 \mathrm{~m} / \mathrm{km})$ and $\mathrm{flatten}$ out to the northeast to $10 \mathrm{ft} / \mathrm{mi}(1.9 \mathrm{~m} / \mathrm{km})$.

This northeast dip may extend over a broader area, as suggested by ground-water movement from the Missouri Coteau. There are large springs along the south and southwest valley walls of the Des Lacs River, while there are almost none on the north and northeast valley wal1s (Lemke, 1960, p. 106).

Roughly perpendicular to the strike of the escarpment is a concealed high-angle fault that has a maximum throw of $80 \mathrm{ft}(24.4 \mathrm{~m})$. From slightly south of the center of sec. 26, T. $160 \mathrm{~N} .$, R. 90 W., the fault strikes N. $57^{\circ}$ E. for a distance of about $2 \mathrm{mi}(3.2 \mathrm{~km})(\mathrm{pl} .4)$. The upthrown side of the fault is to the northwest. This fault may be a growth fault that was activated in post-Niobe, pre-Bonus time as well as post-Bonus time. For further structural interpretations see the drill-hole correlation chart (p1.6). 
Faulting of the Paleocene rocks has also occurred elsewhere along the Missouri Coteau escarpment. Lemke (1960, p. 104) discussed faulting $68 \mathrm{mi}(109 \mathrm{~km})$ to the southeast, near the town of Sawyer. Townsend (1950, p. 1558) described folding and faulting $15 \mathrm{mi}$ (24 km) northwest of Niobe near the town of Lignite (fig. 1). At both locations the faults trend northwest and the downthrown sides lie northeast of the escarpment.

\section{Stratigraphy}

The Sentinel Butte Member, uppermost member of the Fort Union Formation (Paleocene), underlies the surface veneer of early to late Wisconsinan glacial drift (Pleistocene). The Sentinel Butte Member is primarily gray shale, gray to blue silty shale, lignite, and lenticular sandstone and limestone. Generally, the rocks are gray at depth but are lighter in color where weathered.

\section{Lignite}

The Niobe area is based on the Niobe and Bonus lignite beds.

Niobe bed.--The Niobe bed averages $5 \mathrm{ft}(1.5 \mathrm{~m})$, attains a maximum thickness of $8 \mathrm{ft}(2.4 \mathrm{~m})$, and is the more laterally continuous of the two beds (p1. 7). The bed crops out at two localities; elsewhere, it is covered by glacial drift and/or Sentinel Butte rocks. In general, the overburden thickens from $25 \mathrm{ft}(7.6 \mathrm{~m})$ in the northeast to about $200 \mathrm{ft}(61 \mathrm{~m})$ in the southwest and averages $77 \mathrm{ft}(23.5 \mathrm{~m})$ in thickness (p1. 8). 
The demonstrated resources of the Niobe bed are 73 million tons (66 million $t)$, all of which are under less than $120 \mathrm{ft}(37 \mathrm{~m})$ of overburden. Because of lack of data, resources were not calculated for areas where the overburden was greater than $120 \mathrm{ft}$ (37 m). Pollard, Smith and Knox (1972, p. 11) estimated this bed to have 77.1 million tons (69.9 million $t$ ) with a stripping ratio of $10.7 \mathrm{yd}^{3}$ of overburden per ton $\left(9.0 \mathrm{~m}^{3}\right.$ per $\left.t\right)$ of lignite.

Bonus bed.--The Bonus bed is present only near the Coteau escarpment. It overlies the Niobe bed with an average interburden of $36 \mathrm{ft}$ (11 m) (p1. 9). In T. $160 \mathrm{~N} .$, R. 90 W., the interburden thickens in a southeasterly direction from $18 \mathrm{ft}(5.5 \mathrm{~m})$ at the center of sec. 21 to $56 \mathrm{ft}(17 \mathrm{~m})$ in the extreme southeast corner of sec. 26 . East of sec. 26 the interburden thins.

The Bonus bed thickens from $5 \mathrm{ft}(1.5 \mathrm{~m})$ on the northeast subcrop to $11.5 \mathrm{ft}(3.5 \mathrm{~m})$ near the escarpment (p1. 10). The average thickness is $8 \mathrm{ft}(2.4 \mathrm{~m})$. Because of glacial cover, the bed does not crop out. It has been eroded from the upthrown side of the fault that strikes N. $57^{\circ} \mathrm{E}$. and preserved on the downthrown side. The overburden varies from $36 \mathrm{ft}(11 \mathrm{~m})$ to $103 \mathrm{ft}(31 \mathrm{~m})$ and averages $60 \mathrm{ft}(18 \mathrm{~m})(\mathrm{p} 1.11)$ within drilled areas. It may thicken to $200 \mathrm{ft}(61 \mathrm{~m})$ in some locations along the Missouri Coteau. 
The Bonus bed has been replaced by till in holes $311,331,332$, and 333 (p1. 6, correlation section nos. 6, 7, and 10). The coal has been cut out by what appears to be an ice-marginal stream channel that begins in sec. 36, T. 160 N., R. 90 W., and follows a southeasterly course paralleling the escarpment (pl. 5). Other drill holes along this course reveal lower bedrock elevations. The trend of this channel corresponds to the general trend of glacial outwash channels as shown on plate 2 .

The demonstrated resources of the Bonus bed are 49 million tons (44 million $\mathrm{t}$ ), all of which are under less than $120 \mathrm{ft}(37 \mathrm{~m})$ of overburden. Because of lack of data, resources were not calculated for areas where the overburden was greater than $120 \mathrm{ft}(37 \mathrm{~m})$ of overburden. Pollard, Smith, and Knox (1972, p. 11) calculated resources for this bed at 40.3 million tons ( 36.6 million $t$ ) with a stripping ratio of $9.2 \mathrm{yd}^{3}$ of overburden per ton $\left(7.8 \mathrm{~m}^{3} / \mathrm{t}\right)$ of lignite. Pollard, Smith, and Knox (1972, p. 11) reported the following as-received analyses for the Niobe deposit:

\begin{tabular}{c|cccc|c}
\hline \multirow{2}{*}{$\begin{array}{c}\text { Sample } \\
\text { no. }\end{array}$} & \multicolumn{4}{|c|}{ Percent } & Btu/1b \\
\cline { 2 - 6 } & Moisture & $\begin{array}{c}\text { Volatile } \\
\text { matter }\end{array}$ & $\begin{array}{c}\text { Fixed } \\
\text { carbon }\end{array}$ & Ash & Bary \\
\hline 1 & 33.5 & 29.7 & 31.6 & 5.2 & 7,487 \\
2 & 38.5 & 27.6 & 28.3 & 5.6 & 6,749 \\
\hline
\end{tabular}




\section{$\underline{\text { References }}$}

Andrews, D. A., 1939, Geology and coal resources of the Minot region, North Dakota: U.S. Geol. Survey Bu11. 906-B, p. 43-84. Armstrong, C. A., 1969, Geology and ground water resources of Burke and Mountrail Counties--Part 2, Ground water basic data: North Dakota Geol. Survey Bull. 55, 282 p.

Brant, R. A., 1953, Lignite resources of North Dakota: U.S. Geol. Survey Circ. 226, 78 p.

Freers, T. F., 1973, Geology of Burke County, North Dakota: North Dakota Geo1. Survey Bu11. 55, pt. 1, 32 p.

Lemke, R. W., 1960, Geology of the Souris River area, North Dakota: U.S. Geol. Survey Prof. Paper 325, 138 p.

Leonard, A. G., Babcock, E. J., and Dove, L. P., 1925, The 1ignite deposits of North Dakota: North Dakota Geol. Survey Bull. 4, 240 p.

Pettyjohn, W. A., 1968, Geology and ground water resources of Renville and Ward Counties--Part 2, Ground water basic data: North Dakota Geo1. Survey Bull. 50, 302 p.

Pollard, B. C., Smith, J. B., and Knox, C. C., 1972, Strippable lignite reserves of North Dakota: location, tonnage, and characteristics of lignite and overburden: U.S. Bureau of Mines Info. Circ. $8537,37 \mathrm{p}$.

Townsend, R. C., 1950, Deformation of the Fort Union Formation near Lignite, North Dakota: Am. Assoc, of Petroleum Geologists Bull., v. 34, no. 7, p. 1552-1564.

Wilder, F. A., and Wood, L. H., 1902, Report on the lignite by counties, in North Dakota Geo1. Survey Biennial Report 2, v. 1, no. 1: p. 56-162. 